\title{
Subjective and objective cognitive dysfunction in schizophrenia - is there a link?
}

\section{Saffron Homayoun, Frederique Nadeau-Marcotte, David Luck, and Emmanuel Stip ${ }^{\text {* }}$}

Fernand-Seguin Research Centre, Louis-H. Lafontaine Hospital, Montreal, OC, Canada

\section{Edited by:}

Natalie L. Denburg, The University of

Iowa, USA

\section{Reviewed by:}

Giancarlo Dimaggio, Third Center of Cognitive Psychotherapy, Italy

Allison Renee Kaup, San Diego State University and University of California San Diego, USA

\section{${ }^{*}$ Correspondence:}

Emmanuel Stip, Fernand-Seguin Research Centre, 7331 Hochelaga, Montreal, QC, Canada H1N 2V2. e-mail: emmanuel.stip@umontreal.ca
Cognitive dysfunction is a well recognized symptom of schizophrenia, as well as patients having poor insight into their illness. The subjective scale to investigate cognition in schizophrenia (SSTICS) is one of several scales that have been developed to study subjective cognitive dysfunction and has been compared to patients' objective cognitive level. A literature search was performed using PubMed, psychINFO, Web of Science, and cross-referencing to find 26 articles which used 14 different subjective cognitive dysfunction scales to investigate the relationship between subjective and objective measures of cognition in schizophrenia. Although the majority of studies using the SSTICS found significant correlations between subjective and objective measures of cognition, the findings from the other scales were less clear. From this review, the issue of whether or not schizophrenic patients have good cognitive insight remains unsure. However, due to the heterogeneous nature of the study designs and their outcome measures, continued work in this area with consistency on these points is necessary; on the path to better provide management options for a very debilitating component of this illness.

Keywords: subjective, objective, cognitive, insight, schizophrenia, self-assessment

\section{BACKGROUND}

The presence of cognitive dysfunction in patients with schizophrenia has long been recognized (O'Carroll, 1992; Heinrichs and Zakzanis, 1998; Fioravanti et al., 2005), notably in the areas of attention, memory and executive function (Gold and Harvey, 1993). They are found in up to $75 \%$ of patients (Goldberg et al., 1998) and are a frequent source of complaint, leading patients to score themselves higher on subjective questionnaires of cognitive dysfunction than healthy controls (Moritz et al., 2001). Cognitive deficits are a major contributor to the functional and social impairment suffered by schizophrenic patients (Addington and Addington, 1999; Bell and Bryson, 2001; Hofer et al., 2005) and have been noted to have more of an impact on daily life than a patient's positive and negative symptoms (Green, 1996). Cognitive dysfunction in schizophrenia is generally associated with a poor outcome (Green et al., 2000; Bodnar et al., 2008), which has led to the development of cognition targeted treatments such as pharmacological agents, aided by the National Institute of Mental Health initiative entitled "measurement and treatment research to improve cognition in schizophrenia" (MATRICS; Marden and Fenton, 2004).

It has also been well documented that patients with schizophrenia have a specifically poor level of insight into their condition in comparison to other mental health disorders (Amador et al., 1994; Pini et al., 2001), affecting approximately $30-80 \%$ of patients (Amador and Gorman, 1998; Cuesta et al., 2000). Poor insight is again linked to poor clinical outcome and also contributes to compliance (Smith et al., 1999; Buckley et al., 2007). Medication non-compliance is estimated to be at a level of $42 \%$ in the schizophrenic population (Cramer and Rosenheck, 1998) and is associated with a wide range of adverse consequences such an increased risk of relapse (Fenton et al., 1997) and re-hospitalization (Weiden et al., 2004). If this lack of insight into the need for treatment extends to cognitive symptoms as well, then this will have a huge impact on how it is managed, and affect all stages of the process from referral, to monitoring progress, and assessing improvement.

One way to assess patient insight into their cognitive deficits is to use subjective scales, and since the first mention of these "basic symptoms" by Huber (1957), several such instruments have been developed and tested for validity with objective neuro-cognitive tests.

The subjective scale to investigate cognition in schizophrenia (SSTICS) was developed by our research center and published by Stip et al. (2003). The design aim was to develop a simple and ecological scale to assess patients' subjective experiences of cognitive impairment as indicated from objective tests. The scale eventually consisted of 21 Likert-type questions set in the context of everyday activities and situations.

This review aims to give an up-to-date account of studies which have used scales of subjective cognitive deficits in schizophrenia alongside objective assessments of cognition. In accessing the degree of correlation between subjective and objective tests we focus on the question of whether schizophrenic patients are just as hindered in their insight into their cognitive dysfunction as in their illness overall. If indeed patient insight is less affected in the domain of cognition, therapies targeted in this area could theoretically increase compliance and thus patient outcome. Designers of clinical trials measuring the effectiveness of schizophrenia treatments in general may wish to incorporate measures of cognitive dysfunction into their study. And so, better understanding of the relationship between subjective and objective measures of cognitive dysfunction in schizophrenia will also serve to help guide the choice of clinical trial outcome measures. 


\section{LITERATURE}

A search within MEDLINE, psychINFO, and Web of Science using the criteria "subjective, cognition, schizophrenia" was performed. After filtering and cross-referencing, a total of 26 articles were found which used a scale to assess subjective cognitive dysfunction in schizophrenia patients and then compared scores to objective measures. The SSTICS was the most frequently used scale, being found in 10 of the 26 studies.

\section{FINDINGS}

A total of 14 different scales that have been used to assess subjective cognitive dysfunction in schizophrenia patients were identified from the literature search and summarized in Table 1. Twelve of the scales were self-rated and two were interview based, seven were designed for patients with schizophrenia, one for patients with psychosis, one for those with known cognitive deficits, and five were designed for a non-specific patient group. Eleven scales covered more than one cognitive domain.

Table 1 | subjective scales to assess cognitive dysfunction.

\begin{tabular}{|c|c|c|c|c|}
\hline Scale name & Authors & Population & Design & Areas covered \\
\hline $\begin{array}{l}\text { Subjective scale to } \\
\text { investigate cognition in } \\
\text { schizophrenia (SSTICS) }\end{array}$ & $\begin{array}{l}\text { Stip et al. } \\
(2003)\end{array}$ & $\begin{array}{l}\text { Schizophrenia } \\
\text { patients }\end{array}$ & $\begin{array}{l}\text { Self-rated } 21 \text { Likert-type } \\
\text { questions }\end{array}$ & $\begin{array}{l}\text { Memory, attention, executive function, } \\
\text { praxia, language }\end{array}$ \\
\hline $\begin{array}{l}\text { Measure of insight into } \\
\text { cognition-self-rated (MIC-SR) }\end{array}$ & $\begin{array}{l}\text { Medalia et al. } \\
\text { (2008) }\end{array}$ & $\begin{array}{l}\text { Schizophrenia } \\
\text { patients }\end{array}$ & $\begin{array}{l}\text { Self-rated, } 12 \text { items rated on a } \\
\text { scale of frequency 0-3 }\end{array}$ & Attention, memory, executive functioning \\
\hline $\begin{array}{l}\text { Measure of insight into } \\
\text { cognition- clinician-rated } \\
\text { (MIC-CR) }\end{array}$ & $\begin{array}{l}\text { Medalia and } \\
\text { Thysen (2008) }\end{array}$ & $\begin{array}{l}\text { Schizophrenia } \\
\text { patients }\end{array}$ & $\begin{array}{l}\text { Interview, } 12 \text { questions, scale } \\
1-5\end{array}$ & Attention, memory, executive functioning \\
\hline $\begin{array}{l}\text { Schizophrenia cognition } \\
\text { rating scale (SCoRS) }\end{array}$ & $\begin{array}{l}\text { Keefe et al. } \\
(2006)\end{array}$ & $\begin{array}{l}\text { Schizophrenia } \\
\text { patients }\end{array}$ & $\begin{array}{l}\text { Interview } 18 \text { items, } 4 \text { point } \\
\text { scale. Three scores, generated } \\
\text { from patient, informant and } \\
\text { interviewer rating. }\end{array}$ & $\begin{array}{l}\text { Attention, memory, reasoning and problem } \\
\text { solving, working memory, language } \\
\text { production, motor skills. }\end{array}$ \\
\hline $\begin{array}{l}\text { Subjective perception of } \\
\text { attention improvement } \\
\text { questionnaire (SPAIQ) }\end{array}$ & $\begin{array}{l}\text { López-Luengo } \\
\text { (2000) }\end{array}$ & $\begin{array}{l}\text { Schizophrenia } \\
\text { patients }\end{array}$ & Self-rated, 7 point Likert scale & Attention \\
\hline $\begin{array}{l}\text { Eppendorf schizophrenia } \\
\text { inventory (ESI) }\end{array}$ & Mass (2000) & $\begin{array}{l}\text { Schizophrenia } \\
\text { patients }\end{array}$ & $\begin{array}{l}\text { Self-rated, } 138 \text { items, } 4 \\
\text { subscales, on a } 4 \text { point Likert } \\
\text { scale }\end{array}$ & $\begin{array}{l}\text { Attention and speech impairment (AS), } \\
\text { ideas of reference (IR), auditory uncertainty } \\
(A U) \text {, deviant perception (DP). }\end{array}$ \\
\hline $\begin{array}{l}\text { Frankfurt complaint } \\
\text { questionnaire (FCQ) }\end{array}$ & $\begin{array}{l}\text { Süllwold } \\
\text { (1977) }\end{array}$ & $\begin{array}{l}\text { Schizophrenia } \\
\text { patients }\end{array}$ & Self-rated, 98 yes/no questions & $\begin{array}{l}10 \text { subscales in four factors of: central } \\
\text { cognitive disturbances, perception and } \\
\text { motility, depressivity, internal and external } \\
\text { overstimulation }\end{array}$ \\
\hline $\begin{array}{l}\text { Work-readiness cognitive } \\
\text { screen (WCS) }\end{array}$ & $\begin{array}{l}\text { Erlanger and } \\
\text { Feldman } \\
\text { (2002) }\end{array}$ & $\begin{array}{l}\text { Populations with } \\
\text { known or suspected } \\
\text { cognitive dysfunction }\end{array}$ & $\begin{array}{l}\text { Self-rated, web based, 10-point } \\
\text { Likert scale, clinician-rated on } 5 \\
\text { point scale }\end{array}$ & $\begin{array}{l}\text { Vocational preferences, work values, } \\
\text { self-confidence in attention, memory, } \\
\text { working, and socializing. }\end{array}$ \\
\hline $\begin{array}{l}\text { Questionnaire for self- } \\
\text { experienced deficits of } \\
\text { attention (FEDA) }\end{array}$ & $\begin{array}{l}\text { Zimmerman } \\
\text { et al. (1991) }\end{array}$ & Non-specific & $\begin{array}{l}\text { Self-rated, } 76 \text { items with } 5 \\
\text { point Likert scale. }\end{array}$ & $\begin{array}{l}\text { Attention-divided, selective memory- } \\
\text { prospective, long term, forgetting } \\
\text { medicines, remembering names. }\end{array}$ \\
\hline Test of Attentional Style (TAS) & $\begin{array}{l}\text { van den Bosch } \\
\text { et al. (1993) }\end{array}$ & Non-specific & $\begin{array}{l}\text { Self-report, } 31 \text { items, } 5 \\
\text { subscales }\end{array}$ & $\begin{array}{l}\text { Attention in everyday life-distractibility, } \\
\text { overload, processing capacity, attentional } \\
\text { control, conceptual control }\end{array}$ \\
\hline $\begin{array}{l}\text { Prospective and retrospective } \\
\text { memory questionnaire } \\
\text { (PRMQ) }\end{array}$ & $\begin{array}{l}\text { Smith et al. } \\
(2000)\end{array}$ & Non-specific & $\begin{array}{l}\text { Self-rated, } 16 \text { items rated on a } \\
5 \text { point Likert scale. }\end{array}$ & Memory \\
\hline $\begin{array}{l}\text { Dysexecutive questionnaire } \\
\text { (DEX) }\end{array}$ & $\begin{array}{l}\text { Wilson et al. } \\
\text { (1996) }\end{array}$ & Non-specific & $\begin{array}{l}\text { Self-rated } 20 \text { items, rate the } \\
\text { frequency of occurrence }\end{array}$ & Dysexecutive characteristics \\
\hline $\begin{array}{l}\text { Cognitive failures } \\
\text { questionnaire (CFQ) }\end{array}$ & $\begin{array}{l}\text { Broadbent } \\
\text { et al. (1982) }\end{array}$ & Non-specific & $\begin{array}{l}\text { Self-rated, } 25 \text { items, } 5 \text { point } \\
\text { Likert scale }\end{array}$ & $\begin{array}{l}\text { Daily cognitive failures such as forgetting } \\
\text { names, confusing left and right. }\end{array}$ \\
\hline $\begin{array}{l}\text { Patient perception of } \\
\text { functioning scale (PPFS) }\end{array}$ & $\begin{array}{l}\text { Ehmann et al. } \\
\text { (2007) }\end{array}$ & Psychotic patients & $\begin{array}{l}\text { Self-rated, six items on a } 5 \\
\text { point Likert scale }\end{array}$ & $\begin{array}{l}\text { Concentration, conversational ability, } \\
\text { thinking clearly, handling money, carrying } \\
\text { out everyday tasks, memory }\end{array}$ \\
\hline
\end{tabular}


A summary of the 26 studies using these scales and comparing results to objective cognitive tests is presented in Table 2 . The results are unclear, with 12 of the 26 studies lending support to the idea that insight into cognitive deficits in schizophrenia is intact, whereas 14 suggest that cognition is no different from other schizophrenia symptoms in terms of insight. In the four cases where a scale was used in more than one study, all verdicts pointed in the same direction for two scales, but four of the 10 studies with the SSTICS differed in their conclusions, and one of three did with the FCQ.

Overall, a wide variety of objective tests of cognition were used to compare against subjective scores, ranging from using the cognitive question on the positive and negative symptom scale interview (PANSS; Kay et al., 1987) to the pencil and paper brief assessment of cognition in schizophrenia (BACS; Keefe et al., 2004) and computer based neuropsychological batteries such as Cambridge neuropsychological test automated battery (CANTAB; Fray et al., 1996).

\section{CONCLUSION}

The aim of this paper was to review the literature on the use of subjective scales to assess cognitive deficits in schizophrenia and to see if these scales could predict results on objective tests. Overall, the findings were inconclusive, with approximately half of the studies supporting the hypothesis and half not. The individual scales however did yield the same outcome in half of the cases where the same scale was used more than once, although this is difficult to interpret due to a small number of studies, except the SSTICS which was used in 10 studies on this topic and showed a correlation with subjective and objective measures of cognitive deficit in six of these.

A number of the studies also included rater and clinician scores of the patient's cognitive dysfunction, and interestingly it seems that as well as the inconclusive findings about the patients' ability to correctly estimate their level of cognitive impairment, the ability of raters and clinician to do this is also variable. Keefe et al. (2006) found that the interviewer score on the SCoRS was correlated to objective tests, even though the informant and patient scores were not. However Moritz et al. (2004) found that in 20-40\% of cases, clinicians rated the patient's memory as normal even though they had significant impairment. López-Luengo and Vázquez (2005) found that there was no significant difference in the scores given by patients and raters on the SPAIQ, and Medalia et al. (2008) saw no difference in schizophrenic patients' and healthy controls' total scores. In Chan et al. (2008) study, neither schizophrenic and schizotypy patients nor healthy controls had subjective cognitive dysfunction scores that correlated with objective results. Indeed Hermann (1982) found that self-rated memory questionnaires given to healthy subjects in the general population bare little relation to actual memory ability. Therefore it seems that lack of insight into cognitive deficits is not just a schizophrenia-specific phenomenon.

Several of the studies reviewed here also included a measure of insight into general illness, as well as investigating cognitive insight by comparing subjective scores to objective tests. Five of the studies on the SSTICS (Chouinard et al., 2003; Stip et al., 2003; Lecardeur et al., 2009; Bengochea Seco et al., 2010; Johnson et al., 2011) looked at the relationship between SSTICS total scores and insight by use of the scale to assess unawareness of mental disorder (SUMD; Amador and Strauss, 1990), or the insight question on the PANSS (Kay et al., 1987), but no significant correlations were found. Medalia et al. (2008) found no correlation between MIC-SR score and the PANSS question on insight and Medalia and Thysen (2008) found that half of the patients in their study using the MIC-CR had no awareness of their cognitive deficit and 39\% of those that did have some awareness were not able to attribute this to mental illness. In Medalia and Thysen (2010) found that 70\% of patients had full insight into their clinical symptoms, whereas only $27 \%$ had full insight into their cognitive symptoms, coming to the conclusion that the issue of insight in schizophrenia is not a unitary concept.

Indeed, Osatuke et al. (2008) point out in their review on the topic of insight in schizophrenia that the issue is far from straight forward. In terms of definition, research suggests that it should be regarded as a continuum, rather than something that a patient either does or does not have (Markova and Berios, 1995). It is also multidimensional, meaning that patients can have awareness of not just the presence of an illness, but also the consequences and need for treatment (Amador and David, 1998). And to further complicate the matter, insight has been recognized to vary within an individual in terms of different clinical aspects of the illness (Peralta and Cuesta, 1994) and even along the course of the disease (Kemp and Lambert, 1995). The reviewers also discuss the many proposed aetiological models of insight in schizophrenia such as it being a defense mechanism, or included as a positive or even negative symptom. They also touch on theories surrounding, neurocognitive deficits as well as an impairment of metacognition, or in other words, the ability to think about thinking, both in terms of oneself and others.

Proponents of the theory that neuro-cognitive deficits play a central role in the lack of insight into illness in schizophrenia, focus particularly on frontal and parietal dysfunction (David, 1999). Indeed there have been associations with the Wisconsin card-sorting test and poor insight (Young et al., 2003) and Drake and Lewis (2003) showed that perseveration was strongly linked to poor insight. Smith et al. (2000) found that symptom misattribution was correlated with card-sorting measures of frontal lobe function although symptom unawareness was largely unrelated to neuro-cognitive functioning, which led them to conclude that insight in schizophrenia is a multidimensional construct. McEvoy et al. (1996) found that the insight and treatment attitudes questionnaire (ITAQ) score was significantly correlated to only one of nine measures of performance on neuro-cognitive tasks, and Medalia and Thysen (2010) found that only performance on the BACS Tower of London Task was correlated with clinical insight. In addition, Donohoe et al. (2009) found that although subjective and objective tests of cognitive dysfunction only correlated in the patients with intact clinical insight, just 33\% of those with poor clinical insight also had poor cognitive insight, again indicating that these two types of insight are fundamentally different in their nature.

In an attempt to clarify this idea that insight into cognitive dysfunction could be distinct from overall insight into schizophrenia, the term "schizoanosognosia" was coined by Stip (2006). Anosognosia derives from the Greek words for disease (nosos) and knowledge (gnosis) and is a term similar in definition to insight and 
Table 2 | subjective scales of cognitive dysfunction in schizophrenia and comparison with objective tests.

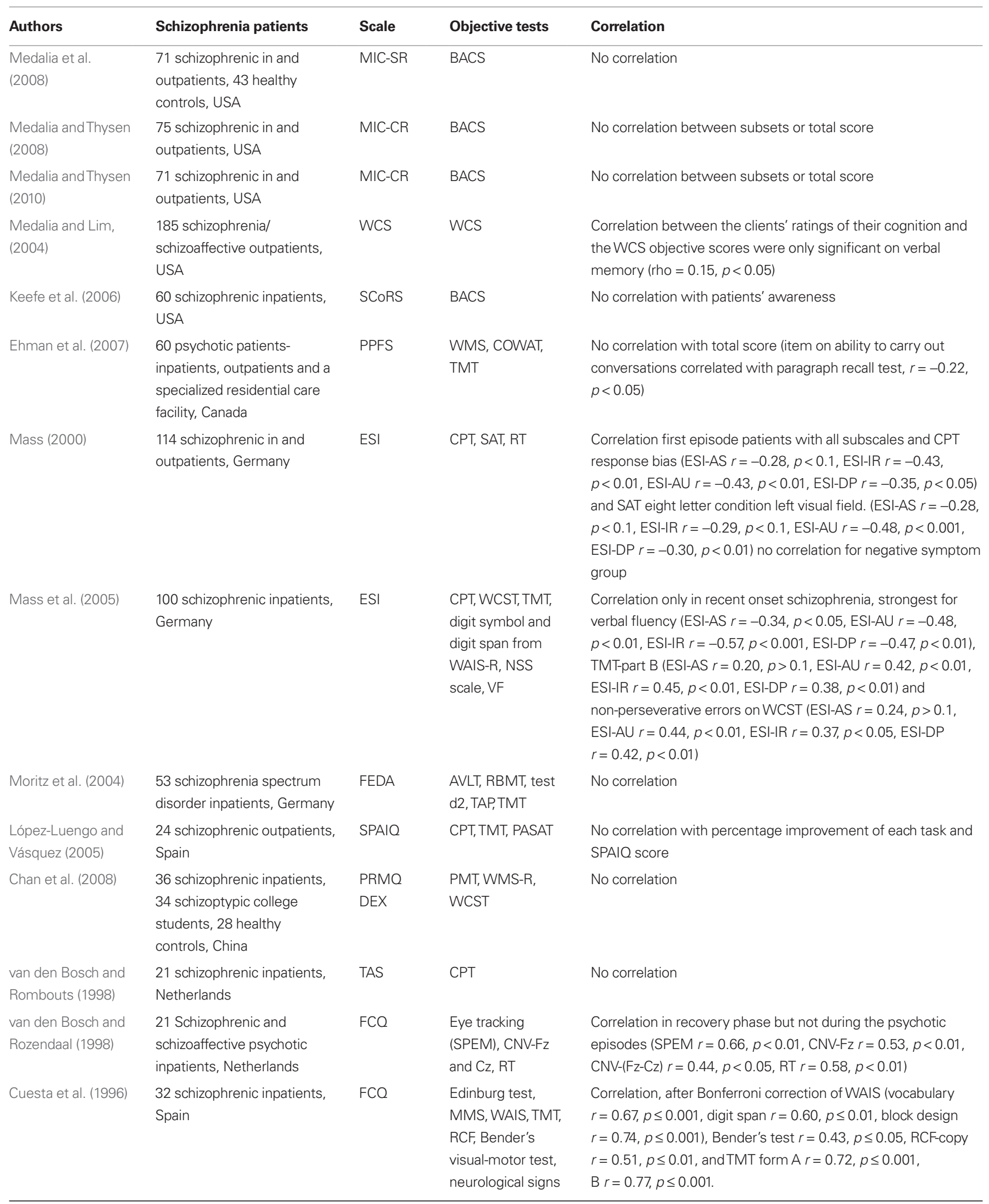


Table 2 | Continued

\begin{tabular}{|c|c|c|c|}
\hline Authors & Schizophrenia patients & Scale & Objective tests \\
\hline $\begin{array}{l}\text { Williams et al. } \\
\text { (1984) }\end{array}$ & $\begin{array}{l}24 \text { schizophrenic inpatients, } \\
\text { UK }\end{array}$ & $\mathrm{FCQ}$ & $\begin{array}{l}\text { WAIS, RT and CRT } \\
\text { Tasks }\end{array}$ \\
\hline $\begin{array}{l}\text { Donohoe et al. } \\
\text { (2009) }\end{array}$ & $\begin{array}{l}51 \text { schizophrenic outpatients, } \\
\text { UK }\end{array}$ & CFO & $\begin{array}{l}\text { WAIS-III, WMS-III, } \\
\text { CANTAB }\end{array}$ \\
\hline
\end{tabular}

\section{Correlation}

No correlation

Correlation $(p<0.05)$ for patients with intact insight with several tests of general cog and episodic memory function (WTAR $r=-0.48$, WAIS vocabulary $r=-0.41$, WMS logical memory I $r=-0.45$, WMS Logical Memory $\| r=-0.37$, WMS faces $\mid r=0.39$, WMS faces $\| r=0.42$ ) no correlation for patients with impaired clinical insight

\begin{tabular}{|c|c|c|c|c|}
\hline $\begin{array}{l}\text { Johnson et al. } \\
\text { (2009) }\end{array}$ & $\begin{array}{l}105 \text { schizophrenic } \\
\text { outpatients, Tunisia }\end{array}$ & $\begin{array}{l}\text { SSTICS } \\
\text { (SACCS) }\end{array}$ & PANSS & $\begin{array}{l}\text { No correlation with total score and the cognitive five factor } \\
\text { model of PANSS }\end{array}$ \\
\hline $\begin{array}{l}\text { Johnson et al. } \\
\text { (2011) }\end{array}$ & $\begin{array}{l}104 \text { schizophrenic } \\
\text { outpatients, Tunisia }\end{array}$ & $\begin{array}{l}\text { SSTICS } \\
\text { (SACCS) }\end{array}$ & $\begin{array}{l}\text { The tunisian } \\
\text { cognitive battery } \\
\text { for patients with } \\
\text { schizophrenia }\end{array}$ & No correlation \\
\hline $\begin{array}{l}\text { Zhornitsky et al. } \\
\text { (2011) }\end{array}$ & $\begin{array}{l}\text { 81, schizophrenia, } \\
\text { schizoaffective or } \\
\text { schizophreniform disorder } \\
\text { outpatients }\end{array}$ & SSTICS & CANTAB & No correlation \\
\hline $\begin{array}{l}\text { Chouinard et al. } \\
\text { (2003) }\end{array}$ & $\begin{array}{l}27 \text { schizophrenic outpatients, } \\
\text { Canada }\end{array}$ & SSTICS & RBANS & No correlation \\
\hline $\begin{array}{l}\text { Prouteau et al. } \\
\text { (2004) }\end{array}$ & $\begin{array}{l}73 \text { schizophrenic outpatients, } \\
\text { Canada }\end{array}$ & SSTICS & $\begin{array}{l}\text { CANTAB } \\
\text { visuo-spatial tests }\end{array}$ & $\begin{array}{l}\text { Correlation for attention section of SSTICS with explicit } \\
\text { memory }(B=-2.61, R p=-0.31, p=0.01) \text { and planning tasks } \\
(B=-2.31, R p=-0.27, p=0.02) \text { and executive functioning } \\
\text { section with the explicit memory task }\left(B=-3.23, R_{p}=-0.37 \text {, }\right. \\
p=0.002)\end{array}$ \\
\hline Potvin et al. (2005) & $\begin{array}{l}76 \text { schizophrenic or } \\
\text { schizoaffective outpatients, } \\
\text { Canada }\end{array}$ & SSTICS & CANTAB & $\begin{array}{l}\text { Correlation in two stages of paired associates learning task } \\
(r=-0.372, p=0.017 \text { and } r=-0.361, p=0.02)\end{array}$ \\
\hline Hake et al. (2007) & $\begin{array}{l}20 \text { schizophrenic or } \\
\text { schizoaffective outpatients, } \\
\text { USA }\end{array}$ & SSTICS & WCST & $\begin{array}{l}\text { Correlation with non-learners group had highest executive } \\
\text { functioning scores on SSTICS [ } t(\mathrm{df}=18)=2.29, p=0.03 \text { ] }\end{array}$ \\
\hline $\begin{array}{l}\text { Lecardeur et al. } \\
\text { (2009) }\end{array}$ & $\begin{array}{l}176 \text { schizophrenia, } \\
\text { schizoaffective or delusional } \\
\text { disorder outpatients, Canada }\end{array}$ & SSTICS & $\begin{array}{l}\text { Cognition section } \\
\text { of PANSS }\end{array}$ & Correlation $(r=0.338, p=0.004)$ \\
\hline Stip et al. (2003) & $\begin{array}{l}\text { 114, schizophrenia, } \\
\text { schizophreniform, } \\
\text { schizoaffective outpatients, } \\
\text { Canada }\end{array}$ & SSTICS & $\begin{array}{l}\text { COWAT, RAVLT, } \\
\text { TMT }\end{array}$ & $\begin{array}{l}\text { Correlation with explicit memory measure }(r=-0.224 \\
p=0.0009)\end{array}$ \\
\hline $\begin{array}{l}\text { Bengochea Seco } \\
\text { et al. (2010) }\end{array}$ & $\begin{array}{l}46 \text { schizophrenic outpatients, } \\
\text { Spain }\end{array}$ & SSTICS & $\begin{array}{l}\text { Cognitive factor } \\
\text { component of } \\
\text { PANSS. barcelona } \\
\text { battery }\end{array}$ & $\begin{array}{l}\text { Correlation with barcelona battery subtests and SSTICS daily } \\
\text { living factor ( } r=0.612 ; p<0.05 \text { ) and SSTICS total score with } 3 \\
\text { subtests-(direct digits } r=-0.385, p<0.05 \text {, "P"-words } \\
r=-0.325, p<0.01 \text {, Key numbers } r=-0.346, p<0.01 \text { ) no } \\
\text { correlation which PANSS }\end{array}$ \\
\hline
\end{tabular}

AVLT, auditory verbal learning test; BACS, brief assessment of cognition in schizophrenia; BVMT, Bender's visual-motor test; CANTAB, Cambridge neuropsychological test automated battery; CNV-Fz, contingent negative variation-frontal midline position; CNV Cz, contingent negative variation, central midline position; COWAT, controlled oral word association test; CPT, continuous performance task; CRT, choice reaction time; MMS, mini-mental state; NSS Scale, neurological soft signs scale; PASAT, paced auditory serial addition task; PMT, prospective memory tasks; RAVLT, Rey auditory verbal learning test; RBANS, repeatable battery for assessment of neuropsychological status; RBMT, rivermead behavioral memory test; RCF, Rey's complex figure; RT, reaction time;

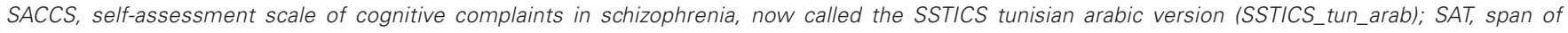

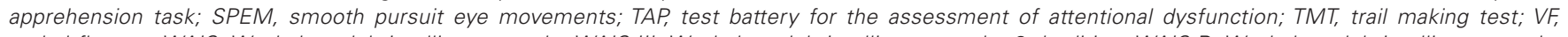

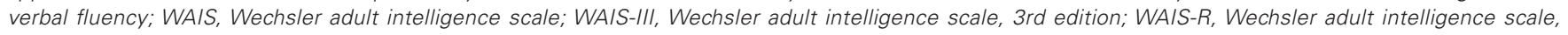

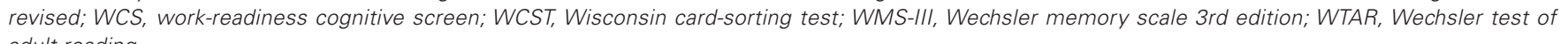
adult reading. 
originally used to describe patients with prefrontal cortical damage. Patients with prefrontal lesions typically display less concern and a lack of regulation and control of their behavior, leading to abnormalities in self-awareness. Indeed Langevin and Legal (1999) drew a parallel with frontal lobe dysfunction and schizophrenia in terms of metacognition and we can postulate that it is a malfunction of the control function of the metacognitive system as described by Frith (1992) that can lead to a lack of self-awareness about a cognitive dysfunction, distinct from the traditional, and less specific term of insight.

A number of studies have used the metacognition assessment scale (MAS; Semerari et al., 2003) to further understand the relationship between metacognition, neurocognition, and insight. Lysaker et al. (2008) found links with the MAS and an executive function tool, and Lysaker et al. (2011) demonstrated significant links with the SUMD insight scale. Lysaker et al. (2005) saw that understanding of one's own mind correlated with better neurocognitive functioning across a number of domains, especially verbal memory, as well as being associated with less emotional withdrawal in the form of a greater depressed mood. This highlights a potential disadvantage of having greater metacognitive and neuro-cognitive function, in that patients experience the pain of having their illness to a greater degree. However, the complexity of the situation is revealed in that although better metacognition is linked with improved treatment outcomes (Roncone et al., 2002), it is also linked with more depression as mentioned above, where Sands and Harrow (1999) found that having a co-morbid diagnosis of depression with schizophrenia leads to an overall poorer patient outcome.

\section{LIMITATIONS}

One of the major limitations of this review is the heterogeneity in the target population, style, length, and cognitive areas covered by the scales used to assess subjective cognitive dysfunction in schizophrenia. There is also a bias in the numbers of studies using the SSTICS and several also have small sample sizes, which all together limit their reliability and ability for generalization. The argument of ecological validity of objective cognition tests must also be considered, as the laboratory settings and tests are very different from the day to day environment of the patient. In addition, the psychometric properties of the subjective measures should be questioned as the reliability and validity of each scale is not always known and these limitations can in turn give a false impression of the actual links between subjective and objective measures of cognitive dysfunction in schizophrenia.

There is also the issue of patient populations differing between studies, for example in medications, chronicity of illness, inpatients or outpatients, and the country where the study was conducted, which could all generate potential confounding factors. Another limitation is the unequal distribution and a general lack of focus on the gender of patients. It is well established that there are a number differences in male and female schizophrenic patients, such as symptomatology (Hafner, 2003), where males generally have more negative symptoms and females display more affective symptoms. There are also differences in IQ (Flor-Henry, 1985) and brain anatomy (Goldstein et al., 2001) and even insight into clinical symptoms (Grossman et al., 2008), which could also have an effect on cognition and the subjective perception of dysfunction in this area. Indeed Cuesta et al. (1996) did find that female patients had significantly higher complaint scores on the FCQ, however it must be noted that there were only six females from a small sample of just 32 patients. Similar under representation of females is seen in most of the other studies in this review, with only van den Bosch and Rombouts (1998) having an equal number of males and females in their study.

Another potential limitation of this review is that within studies, results from objective and subjective tests of cognitive dysfunction were not compared in a domain specific fashion. This generalizes the findings from the subjective and objective tests and may have lead to a masking of associations in particular areas. In a number of papers, this information was simply not included, and the importance of this is demonstrated by results from the SSTICS in particular, which suggest that the relationship between subdivisions of cognition on subjective scales and their corresponding areas on objective tests is not necessarily straight forward. Stip et al. (2003) pointed out that in the cognitive domain of memory; only the global SSTICS score was reliable. In addition, Prouteau et al. (2004) found that although there was no correlation with objective memory dysfunction and memory complaints, the former was correlated with attention complaints and objective executive functioning scores, and that subjective complaints of executive functioning were correlated with objective memory scores.

This discrepancy between the cognitive performance of executive functioning and the subject's perception of it, could suggest a malfunction of the control function of the metacognitive system. Indeed, the same function of "control" that allows good planning. The discrepancy between perception of memory deficits and objective memory scores, also suggests a dysfunction of the monitoring process that informs the metacognitive system on the state of the cognitive system.

The gap between objective and the subjective cognitive constructs could be the long term result of a malfunction in bottomup monitoring which collects information on cognitive tasks in order to supply and enrich the "model" of the cognitive system contained in the metacognitive system. In fact Stip et al. (2003) noted that factorial grouping based on the responses of patients with schizophrenia differed from that worked out from cognitive neuropsychology models. Thus, elements usually placed in the field of memory, could find themselves in that of attention, according to patient perceptions.

\section{FURTHER RESEARCH}

Due to the aforementioned correlation with poor insight, the potential for aiding medication compliance and thus overall patient outcome is immense if there is indeed greater insight of cognitive impairments in schizophrenia compared to the other domains of insight into this illness. We can imagine that adherence to the recent developments in cognitive enhancing pharmacological and psychological treatments may also suffer from poor insight, but before more is known on the complex issue of insight in schizophrenia, it is reassuring to learn that Medalia et al. (2009) found that patients who participated in a short psycho-educational therapy called Brain check that taught them about cognitive dysfunction in mental illness, had more self-awareness about their own cognitive deficits than those who had not participated. 
This review demonstrates that current knowledge on this subject is inconclusive and that at present there is no consensus on a reliable method to be used to identify schizophrenic patients most in need of cognitive therapies, apart from sometimes lengthy and costly objective tests of cognition. Further research could be directed toward initially ensuring and improving the reliability and validity of current subjective tests of cognitive dysfunction in schizophrenia to limit the times that that null hypotheses are being reached for methodological reasons alone. Looking at specific cognitive domains being tested with the subjective and objective measures could help reveal currently unnoticed associations and also explore the aforementioned

\section{REFERENCES}

Addington, J., and Addington, D. (1999). Neurocognitive and social functioning in schizophrenia. Schizophr. Bull. $25,173-182$.

Amador, X. F., and David, A. S. (1998). Insight and Psychosis. New York: Oxford University Press.

Amador, X. F., and Gorman, J. (1998). Psychopathologic domains and insight in schizophrenia. Psychiatr. Clin. North Am. 21, 27-42.

Amador,X. F., and Strauss, D.H. (1990). The Scale to Assess Unawareness of Mental Disorder. New York Psychiatric Institute, Columbia University, New York.

Amador, X. F, Flaum, M., Andreasen, N. C., Strauss, D. H., Yale, S. A., Clark, S., and Gorman, J. M. (1994). Awareness of illness in schizophrenia, schizoaffective, and mood disorders. Arch. Gen. Psychiatry 51, 826-836.

Bell, M. D., and Bryson, G. (2001). Work rehabilitation in schizophrenia: does cognitive impairment limit improvement? Schizophr. Bull. 27, 269-279.

Bengochea Seco, R., Gil Sanz, D., and Fernández Modamio, M. (2010). Cognitive complaints in schizophrenia: relationship with insight and other cognitive measures. Rev. Psiquiatr. Salud Men.(Barc.) 3, 55-60.

Bodnar, M., Malla, A., Joober, R., and Lepage, M. (2008). Cognitive markers of short-term clinical outcome in firstepisode psychosis. Br. J. Psychiatry 193, 297-304.

Broadbent, D. E., Cooper, P. F., FitzGerald, P., and Parkes, K. R. (1982). The cognitive failures questionnaire (CFQ) and its correlates. Br. J. Clin. Psychol. 21(Pt 1), 1-16.

Buckley, P. F., Wirshing, D. A., Bhushan, P., Pierre, J. M., Resnick, S. A., and Wirshing, W.C. (2007). Lack of insight in schizophrenia: impact on treatment adherence. CNS Drugs 21, 129-141.

Chan, R., Wang, Y., Ma, Z., Hong, X., Yuan, Y., Yu, X., Li, Z., Shum, D., and Gong, Q. (2008). Objective measures of prospective memory do not correlate with subjective complaints in schizophrenia. Schizophr. Res. 103, 229-239.
Chouinard, S., Stip, E., Comtois, G., Corbière, M., Bolé, P., Lamontagne, L., Lecavalier, M., and Beauregard, F. (2003). Retour à l'école de jeunes patients souffrant de troubles mentaux graves: premier regard sur un projet pilote montréalais. Sante Ment. Que. 28, 273-290.

Cramer, J. A., and Rosenheck, R. (1998). Compliance with medication regimens for mental and physical disorders. Psychiatr. Serv. 49, 196-201.

Cuesta, M. J., Peralta, V., and Zarzuela, A. (2000). Reappraising insight in psychosis: multi-scale longitudinal study. Br. J. Psychiatry 177, 233-240.

Cuesta, M. J., Peralta, V., and Juan, J. A. (1996). Abnormal subjective experiences in schizophrenia: its relationships with neuropsychological disturbances and frontal signs. Eur. Arch. Psychiatry Clin. Neurosci. 246, 101-105.

David,A.S. (1999). “To see oursels as others see us”. Aubrey Lewis's insight. $B r$. J. Psychiatry 175, 210-216.

Donohoe, G., Hayden, J., McGladen, N., O'Gráda, C., Burke, T., Barry, S., Behan, C., Dinan, T. G., O'Callaghan, E., Gill, M., and Corvin, A. P. (2009). Is "clinical" insight the same as "cognitive" insight in schizophrenia? J. Int. Neuropsychol. Soc. 15, 471-475.

Drake, R. J., and Lewis, S. W. (2003). Insight and neurocognition in schizophrenia. Schizophr. Res. 62, 165-173.

Ehmann, T. S., Goldman, R., Yager, J., $\mathrm{Xu}$, Y., and MacEwan, G. W. (2007). Self-reported cognitive and everyday functioning in persons with psychosis: the patient perception of functioning scale. Compr. Psychiatry 48, 597-604.

Erlanger, D. M., and Feldman, D. J. (2002). Headminderk WorkReadiness Cognitive ScreenSM (WCS) Professional Manual. New York: Headminder, Inc. and Pan Medix, Inc. Fenton, W. S., Blyer, C., and Heinssen, R. K. (1997). Determinants of medication compliance in schizophrenia: empirical and clinical findings. Schizophr. Bull. 23, 637-651.

discrepancies when comparisons are made. Generalizability would be increased with larger population sizes and more equal numbers of males and females. Longitudinal studies could additionally address the issue of changes in insight being affected by clinical course.

Better understanding of this important and difficult to tackle area of cognitive insight in schizophrenia is eagerly awaited. In doing so, benefits for patient outcome are readily anticipated, through better comprehension and management by medical practitioners as well as improved clinical trial effectiveness by the inclusion of cognitive dysfunction measures to recognize successful treatments for this frequently debilitating disease.

Fioravanti, M., Carlone, O., Vitale, B., Cinti, M. E., and Clare, L. (2005). A meta-analysis of cognitive deficits in adults with a diagnosis of schizophrenia. Neuropsychol. Rev. 15, 73-95.

Flor-Henry, P. (1985). Schizophrenia: sex differences. Can. J. Psychiatry 30, 319-322.

Fray, P. J., Robbins, T., and Sahakian, B. J. (1996). Neuropsychiatric applications of CANTAB. Int. J. Geriatr. Psychiatry 11, 329-336.

Frith, C. D. (1992). The Cognitive Neuropsychology of Schizophrenia. Hove: Erlbaum, 113-132.

Gold, J. M., and Harvey, P. D. (1993). Cognitive deficits in schizophrenia. Psychiatr. Clin. NorthAm. 16, 295-312.

Goldberg, T. E., Kelsoe, J. R., Weinberger, D. R., Pilskin, N. H., Kirwin, P. D., and Berman, K. F. (1988). Performance of schizophrenic patients on putative neuropsychological tests of frontal lobe function. Int. J. Neurosci. 42, 51-58.

Goldstein, J. M., Seidman, L., Horton, N. J., Makris, N., Kennedy, D. N., Caviness Jr, V. S., Faraone, S. V., and Tsuang, M. T. (2001). Normal sexual dimorphism of the adult human brain assessed by in vivo magnetic resonance imaging. Cereb. Cortex 11, 490-497.

Green, M. F. (1996). What are the functional consequences of neurocognitive deficits in schizophrenia? Am. J. Psychiatry 153, 321-330.

Green, M. F., Kern, R. S., Braff, D. L., and Mintz, J. (2000). Neurocognitive deficits and functional outcome in schizophrenia: are we measuring the "right stuff." Schizophr. Bull. 26, 119-136.

Grossman, L. S., Harrow, M., Rosen, C. Faull, R., and Strauss, G. P. (2008). Sex differences in schizophrenia and other psychotic disorders: a 20-year longitudinal study of psychosis and recovery. Compr. Psychiatry 49, 523-529.

Hafner, H. (2003). Gender differences in schizophrenia. Psychoneuroendocrinology 2, 17-54.

Hake, D. L., Hamera, E., and Rempfer, M. (2007). Self-report of cognitive functioning and learning in schizophrenia.
J. Am. Psychiatr. Nurses Assoc. 13, 93-100.

Heinrichs, R. W., and Zakzanis, K. K. (1998). Neurocognitive deficit in schizophrenia: a quantitative review of the evidence. Neuropsychology 12 , 426-445.

Hermann, D. J. (1982). Know thy memory: the use of questionnaires to assess and study memory. Psychol. Bull. 92, 434-452.

Hofer, A., Baumgartner, S., Bodner, T., Edlinger, M., Hummer, M., Kemmler, G., Rettenbacher, M., and Fleischhacker, W. (2005). Patient outcomes in schizophrenia II: the impact of cognition. Eur. Psychiatry 20, 395-402.

Huber, G. (1957). Pneumenzephalographische und psychopathologische bilder bei endogenen psychosen. Berlin: Springer.

Johnson, I., Kebir, O., Ben Azouz, O., Dellagi, L., Rabah, Y., and Tabbane, K. (2009). The self-assessment scale of cognitive complaints in schizophrenia: a validation study in Tunisian population. BMC Psychiatry 9, 66. doi: 10.1186/1471-244X-9-66

Johnson, I., Tabbane, K., Dellagi, L., and Kebir, O. (2011). Self-perceived cognitive functioning does not correlate with objective measures of cognition in schizophrenia. Compr. Psychiatry. doi: 10.1016/j.comppsych.2010.12.008

Kay, S. R., Fitzbein, A., and Opler, L. A. (1987). The positive and negative symptom scale (PANSS) for schizophrenia. Schizophr. Bull. 13, 261-267.

Keefe, R. S. E., Goldberg, T., Harvey, P. D., Gold, J.M., Poe, M., and Coughenour, L. (2004). The brief assessment of cognition in schizophrenia: reliability, sensitivity, and comparison with a standard neurocognitive battery. Schizophr. Res. 68, 283-297.

Keefe, R. S. E., Poe, M., Walker, T., Kang, J., and Harvey, P. (2006). The schizophrenia cognition rating scale: an interview-based assessment and its relationship to cognition, real-world functioning, and functional capacity. Am. J. Psychiatry 163, 426-432. 
Kemp, R. A., and Lambert, T. J. R. (1995). Insight in schizophrenia and its relationship to psychopathology. Schizophr. Res. 18, 21-28.

Langevin, P., and Legal, D. (1999). "L'agnosognosie secondaire à une atteinte frontale," in Neuropsychologie des lobes frontaux eds. M. Van der Linden, and X. Seron (Marseilles: Solal), 289-308.

Lecardeur, L., Briand, C., Prouteau, A., Lalonde, L., Nicole, L., Lesage, A., and Stip, E. (2009). Preserved awareness of their cognitive deficits in patients with schizophrenia: convergent validity of the SSTICS. Schizophr. Res. 107, 303-306.

López-Luengo, B. (2000). Rehabilitación cognitiva en esquizofrenia: aplicación del APT (Attention Process Training). Doctoral dissertation, Complutense University of Madrid, Spain.

López-Luengo, B., and Vázquez, C. (2005). Effects of a neuropsychological rehabilitation programme on schizophrenic patients' subjective perception of improvement. Neuropsychol. Rehabil. 15, 605-618.

Lysaker, P. H., Carcione, A., Dimaggio, G., Johannesen, J. K., Nicol, G., Procacci, M., and Semerari, A. (2005). Metacognition amidst narratives of self and illness in schizophrenia: associations with neurocognition, symptoms, insight and quality of life. Acta Psychiatr. Scand. 112, 64-71.

Lysaker, P. H., Dimaggio, G., Buck, K. D., Callaway, S. S., Salvatore, G., Carcione, A., Nicolò, G., and Stanghellini, G. (2011). Poor insight in schizophrenia: links between different forms of metacognition with awareness of symptoms, treatment need, and consequences of illness. Compr. Psychiatry 52, 253-260.

Lysaker, P. H., Warman, D. M., Dimaggio, G., Procacci, M., LaRocco, V.A., Clark, L. K., Dike, C.A., and Nicolo, G. (2008). Metacognition in Schizophrenia: associations with multiple assessments of executive function. J. Nerv. Ment. Dis. 196, 384-389.

Marden, S. R., and Fenton, W. (2004). Measurement and treatment research to improve cognition in schizophrenia: NIMH MATRICS initiative to support the development of agents for improving cognition in schizophrenia. Schizophr. Res. 72, 5-9.

Markova, I. S., and Berios, G. E. (1995). Insight in clinical psychiatry. J. Nerv. Ment. Dis. 183, 743-751.

Mass, R. (2000). Characteristic subjective experiences of schizophrenia. Schizophr. Bull. 26, 921-931.

Mass, R. T., Haasen, C., and Borgart, E. J. (2005). Abnormal subjective experiences of schizophrenia: evaluation of the Eppendorf schizophrenia inventory. Compr. Psychiatry 135, 91-101.

McEvoy, J. P., Hartman, M., Gottlieb, D., Godwin, S., Apperson, L. J., and Wilson, W. (1996). Common sense, insight, and neuropsychological test performance in schizophrenia patients. Schizophr. Bull. 22, 635-641. Medalia, A., Choi, J., Schwalbe, E., and King, E. (2009). Efficacy of a brief intervention to improve awareness of neurocognitive deficit in schizophrenia. Schizophr. Bull. 35, 351.

Medalia, A., and Lim, R. (2004). Selfawareness of cognitive functioning in schizophrenia. Schizophr. Res. 71, 31-338.

Medalia, A., and Thysen, J. (2008). Insight into neuro-cognitive dysfunction in schizophrenia. Schizophr. Bull. 34, 1221-1230.

Medalia, A., and Thysen, J. (2010). A comparison of insight into clinical symptoms versus insight into neurocognitive symptoms in schizophrenia. Schizophr. Res. 118, 134-139.

Medalia, A., Thysen, J., and Freilich, B. (2008). Do people with schizophrenia who have objective cognitive impairment identify cognitive deficits on a self report measure? Schizophr. Res. 105, 156-164.

Moritz, S., Ferahli, S., and Naber, D. (2004). Memory and attention performance in psychiatric patients: lack of correspondence between clinicianrated and patient-rated functioning with neuropsychological test results. J. Int. Neuropsychol. Soc. 10, 623-633. Moritz, S., Lambert, M., Andresen, B., Bothern, A., Naber, D., and Krausz, M. (2001). Subjective cognitive dysfunction in first-episode and chronic schizophrenic patients. Compr. Psychiatry $42,213-216$.

O'Carroll, R.E. (1992). Neuropsychology of psychosis. Curr. Opin. Psychiatry 5 , 38-44.

Osatuke, K., Ciesla, J., Kasckow, J. W., Zisook, S., and Mohamed, S. (2008). Insight in schizophrenia: a review of etiological models and supporting research. Compr. Psychiatry 49, 70-77.

Peralta, V., and Cuesta, M. J. (1994). Lack of insight: its status within schizophrenic psychopathology. Biol. Psychiatry 36, 559-561.

Pini, S., Cassano, G., Dell'Osso, L., and Amador, X. (2001). Insight into illness in schizophrenia, schizoaffective disorder, and mood disorders with psychotic features. Am. J. Psychiatry 158, 122-125.

Potvin, S., Briand, C., Prouteau, A., Bouchard, R.-H., Lipp, O., Laldone, P., Nicole, L., Lesage, A., and Stip, E. (2005). CANTAB explicit memory is less impaired in addicted schizophrenia patients. Brain Cogn. 59, 38-42.
Prouteau, A., Verdoux, H., Briand, C. Lesage, A., Laldone, P., Nicole, L., Reinharz, D., and Stip, E. (2004). Selfassessed cognitive dysfunction and objective performance in outpatients with schizophrenia participating in a rehabilitation program. Schizophr. Res. 69, 85-91.

Roncone, R., Falloon, I. R., Mazza, M., De Risio, A., Pollice, R., Necozione, S., Morosini, P., and Casacchia, M. (2002). Is theory of mind in schizophrenia more strongly associated with clinical and social function than with neurocognitive deficit? Psychopathology 35 , 280-288.

Sands, J. R., and Harrow, M. (1999). Depression during the longitudinal course of schizophrenia. Schizophr. Bull. 25, 157-171.

Semerari, A., Carcione, A., Dimaggio, G, Falcone, M., Nicolo, G., Procaci, M., and Alleva, G. (2003). How to evaluate metacognitive function in psychotherapy? The metacognition assessment scale its applications. Clin. Psychol. Psychother. 10, 238-261.

Smith, T., Hull, J., Israel, L., and Willson, D. (2000). Insight, symptoms, and neurocognition in schizophrenia and schizoaffective disorder. Schizophr. Bull. 26, 193-200.

Smith, T. E., Hull, J. W., Goodman, M., Hedayat-Harris, A., Willson, D. F., Israel, L. M., and Munich, R. L. (1999). The relative influences of symptoms, insight, and neurocognition on social adjustment in schizophrenia and schizoaffective disorder.J. Nerv. Ment. Dis. 187, 102-108.

Stip, E. (2006) "La Schizophrenie," in Neuropsychologie clinique et neurologie du comportement, eds. T. BotezMarquard and F. Boller (Montréal: Les Presses de l'Universite de Montréal), 523-539.

Stip, E., Caron, J., Renaud, S., Pampoulova, T., and Lecomte, Y. (2003). Exploring cognitive complaints in schizophrenia: the subjective scale to investigate cognition in schizophrenia. Compr. Psychiatry 44, 331-340.

Süllwold, L. (1977). Symptome schizophrener Erkrankungen. Berlin: Springer-Verlag.

van den Bosch, R. J., and Rombouts, R. P. (1998). Casual mechanisms of subjective cognitive dysfunction in schizophrenic and depressed patients. J. Nerv. Ment. Dis. 186, 364-368.

van den Bosch, R. J., Rombouts, R. P., and van Asma, M. J. O. (1993). Subjective cognitive dysfunction in schizophrenia and depressed patients. Compr. Psychiatry 34, 130-136.

van den Bosch, R. J., and Rozendaal, N. (1998). Subjective cognitive dysfunction, eye tracking, and slow brain potentials in schizophrenic and schizoaffective patients. Biol. Psychiatry 7 , 741-746.

Weiden, P. J., Kozma, C., Grogg, A., and Locklear, J. (2004). Partial compliance and risk of rehospitalization among California medicaid patients with schizophrenia. Psychiatr. Serv. 55, 886-891.

Williams, R. M., Alagaratnam, W., and Hemsley, D. R. (1984). Relationship between subjective self-report of $\operatorname{cog}$ nitive dysfunction and objective information-processing performance in a group of hospitalized schizophrenic patients. Eur. Arch. Psychiatr. Neurol. Sci. 234, 48-53.

Wilson, B. A., Alderman, N., Burgess, P. W., Emsley, H., and Evans, J. (1996). Behavioural Assessment of the Dysexecutive Syndrome. Bury St Edmunds: Thames Valley Test Company.

Young, D. A, Campbell, Z.,Zakzanis, K. K., and Weinstein, E. (2003). A comparison between an interview and a selfreport method of insight assessment in chronic schizophrenia. Schizophr. Res. 63, 103-109.

Zhornitsky, S., Potvin, S., Aubin, G., Gélinas, I., and Stip, E. (2011). Relationship between insight into cognition, extrapyramidal symptoms and mental illness in schizophrenia. Aust. N. Z. J. Psychiatry. doi: 10.3109/00048674.2011.561483

Zimmerman, P., Messner,C., Poser, U., and Sedelmeier, P. (1991). Ein Frageboden erlebter Defizite der Aufmerksamkeit (FEDA). Freiburg: Psychologisches Institut der Universität Freiburg.

Conflict of Interest Statement: The authors declare that the research was conducted in the absence of any commercial or financial relationships that could be construed as a potential conflict of interest.

Received: 21 February 2011; accepted: 17 June 2011; published online: 04 July 2011. Citation: Homayoun S, Nadeau-Marcotte F, Luck D and Stip E (2011) Subjective and objective cognitive dysfunction in schizophrenia - is there a link? Front. Psychology 2:148. doi: 10.3389/ fpsyg.2011.00148

This article was submitted to Frontiers in Psychopathology, a specialty of Frontiers in Psychology.

Copyright (c) Homayoun, NadeauMarcotte, Luck and Stip. This is an openaccess article subject to a non-exclusive license between the authors and Frontiers Media SA, which permits use, distribution and reproduction in other forums, provided the original authors and source are credited and other Frontiers conditions are complied with. 